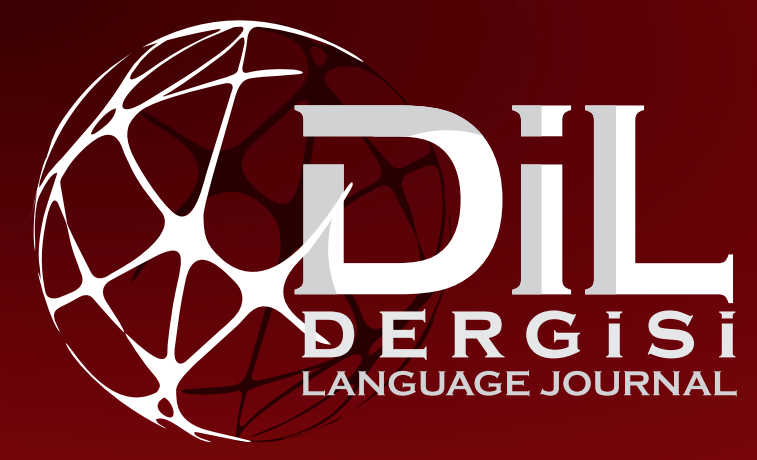

Keywords

Research Articles, Introductions, Function-first

Approach, Verb Tense Usage, Applied Linguistics
Dil Dergisi

Sayı/Number: 170/2

Temmuz/July 2019

Gönderildiği tarih: 12.04.2019

Kabul edildiği tarih: 28.05 .2019

DOI: $10.33690 /$ dilder.580752

\title{
A FUNCTION-FIRST APPROACH TO VERB TENSE USAGE IN RESEARCH ARTICLE INTRODUCTIONS IN APPLIED LINGUISTICS
}

\author{
IŞLEV-ÖNCELIKLI YAKLAŞIM AÇISINDAN UYGULAMALI DILBILIM ALANINDAKI \\ ARAŞTIRMA MAKALELERININ GIRIŞ BÖLÜMLERINDE (FIILDEKI) ZAMAN KULLANIMI \\ - İsmet Öztürk
}

Öğr. Üyesi, Bursa Uludağ Üniversitesi, Ingiliz Dili Eğitimi Anabilim Dalı, iozturk@uludag.edu.tr

\section{Abstract}

The study aims to investigate verb tense usage in research article introductions in the field of Applied Linguistics by adopting a 'function-first' approach. The corpus used in the study consists of 50 research article introductions published in five prominent journals of the field. The communicative function of the sentences was determined on the basis Swales' (1990; 2004) CARS (Create a Research Space) model. In the coding of data Maxqda 11 was used. The results show that each function is associated with particular verb tense. For instance, in 'claiming centrality' the present perfect tense, in 'making topic generalisations' the simple present and in 'reviewing items of previous research' the simple past tense is predominant. The results suggest that the 'function-first' approach provides a more accurate description of verb tense usage in writing research article introductions than the formfirst' approach. The findings have implications for teaching academic writing.
Anahtar Sözcükler

Arastırma Makaleleri, Giris Bölümü, İslev-öncelik| yaklaşım, (Fiildeki) Zaman Kullanımı, Uygulamalı Dilbilim 


\section{Introduction}

In the last few decades, the organisation of research article introductions (RAls) has received considerable attention. Studies have been conducted on the rhetorical organisation of RAls in various academic disciplines (e.g. Samraj, 2002; Öztürk, 2007; Hirano, 2009). In addition to the overall organisation of RAls, which might be called 'macro' structure, the 'micro' organisation of RAls has also attracted the attention of researchers. Issues studied include collocations of grammatical words (Gledhill, 2000), metadiscoursal features used in signalling moves (Del Saz Rubio, 2011), the relationship between lexical bundles and moves (Cortes, 2013), hedging in RAls (Samaie et. al., 2014), verb tense and modality in abstracts (Salager-Meyer , 1992; Tseng, 2011). Surprisingly, there is a lack of studies investigating verb tense usage in RAls. The purpose of the present study is to fill in this gap.

\subsection{Studies Adopting a Form-First Approach}

Studies on verb tense usage in the available literature have generally used the 'form-first' approach. In this approach "patterns are identified entirely based on the recurrence of linguistic forms, with information about how the forms are used only being integrated at a later stage of analysis" (Durrant \& Mathews-Aydınlı, 2011, p. 61).

By adopting this approach, Gunawardena (1989) investigated the use of the present perfect tense in the Introduction, Methods, Results and Discussion sections of research articles in the fields of biology and biochemistry. She found that the present perfect was more common in the introduction section of RAs than in other sections. However, most of the studies in this line of research have focussed on tense usage in academic citations (or reporting literature) rather than specific sections of RAs. Hawes and Thomas (1997, p.397), who studied tense choice in citations in the field of psychosomatic medicine, found that the past tense was the most frequently used tense $(41.6 \%)$, and followed by the present perfect $(32.8 \%)$ and the present tense (25.6\%).

However, these findings contradict with Chen's (2009) results. Chen investigated tense usage of reporting verbs in 100 native English speaker dissertation literature reviews (which "refers to a separate chapter in a dissertation, equal in status with other chapters like Introduction" (p. 139)) and concluded that the simple present was the most frequent tense (70.6\%) followed by the simple past tense $(15.8 \%)$ and the present perfect tense $(8.9 \%)$. The difference between the two studies may have resulted from the fact that Hawes and Thomas (1997) analysed the articles in the corpus as whole whereas Chen (2009) focussed on the literature review chapters in $\mathrm{PhD}$ dissertations, which he equates with the introduction sections of RAs. In a more recent study Hyland and Jiang (2017), who examined the changes in academic citation practices over the past 50 years (1965-1985-2015), argue that while there is "a shift 
towards the past" in Applied Linguistics, in Sociology and Engineering the shift is towards the present tenses (p.78).

As far as the purposes for which the tenses are used (i.e., the function of tenses is concerned), Swales and Feak (2004, p. 183) suggest that the past tense is used in referring to a single study; the present perfect is used in referring to "areas of inquiry"; and, the present tense is used in referring to "state of current knowledge". Hawes and Thomas (1997), on the other hand, claim that

1. Past tense citations with a named researcher as subject provide particulars for a preceding generalisation or basis for a claim.

2. Present tense citations communicate generalized interpretations / conclusions and suggest writer commitment to the information reported.

3. Present Perfect citations highlight the direct relevance of previous studies to the reporting writer's own research write up. (p.413)

In this regard, Gunawardena (1989, p. 271) argues that in reporting previous research "the past tense is used when the writers intend to focus their attention on the occurrence of the event itself, and that the present perfect is used when they intend to focus their attention on the present state of the thing they are talking about". Finally, Chen $(2009$, p.146) suggests that "there are some rules governing the tense usage":

a) the simple present tense of reporting verbs can be used in all the four elements of LRs, b) the simple past tense of reporting verbs can be used to refer to specific research when the writer reviews the previous studies of a subject and indicates research gaps in Elements 2 and $3, c$ ) the present perfect tense of reporting verbs can be used to refer to areas of research, and to make generalizations of a subject in Element 1 , and d) the present future tense of reporting verbs is used to announce the writer's own research in Element $4^{1}$.

However, the studies reported above have provided conflicting results. To begin with the frequency of occurrence, Hawes and Thomas (1997) found that the past tense is the most frequently used tense whereas according to Chen's (2009) findings it is the simple present tense which occurs most frequently. In a recent study, Hyland \& Jiang (2017) suggest that there is a shift from present to past in the field of Applied Linguistics.

1 In this quotation Element 1 refers to "making topic generalisations", Element 2 to "reviews of previous studies on a subject", Element 3 to "indicating research gaps" and Element 4 to "announcing the present research" (p. 144). 
As for the functions of the tenses, there is no agreement between the studies reported above. For instance, regarding the use of the simple past tense Gunawardena (1989, p. 271) argues that it is used "when the writers intend to focus their attention on the occurrence of the event itself". Hawes and Thomas (1997, p. 397) propose that it is used to "provide particulars for a preceding generalization or basis for a claim". Chen (2009, p. 146), on the other hand, claims that it "can be used to refer to specific research when the writer reviews the previous studies of a subject".

It should be pointed out, however, that such information seems to have little pedagogical value for novice and non-native research writers. For instance, knowing that the past tense is the most frequently used tense, and is followed by the present perfect and the present tense in research articles (Hawes \& Thomas, 1997) is unlikely to help novice writers. They need more specific information such as which tense to use in a particular section or parts of a section of a research paper. As emphasised by Durrant and Mathews-Aydınlı (2011, p. 61) "learners need to know what functions they are likely to need to express, what forms most appropriately fulfil those functions, and what variation those forms permit when they are fitted into specific contexts". Therefore, there is a need for 'function-first' analysis of tense usage in research writing.

\subsection{Studies Adopting a Function-First Approach}

In the literature on verb tense usage in academic writing studies adopting a function-first approach are scarce, and the existing studies (e.g., Salager-Meyer, 1992; Tseng, 2011) examine verb tense usage in RA abstracts only. Salager-Meyer's (1992) study can be considered as the first step towards a 'function-first' approach to verb tense usage in research writing. She examined the distribution of verb tenses and modals in Medical English abstracts in terms of a genrebased move analysis. The moves she identifies were purpose, methods, results and conclusions. The 'communicative function' of each abstract move was defined on the basis of the "notes for contributors" and "instructions for authors" sections of four leading medical periodicals ( $p$. 96). For example, the communicative function of the move 'purpose' was defined as "primary objective, central question of the study and questions addressed by the article" (p. 110). The analysis involved examining the distribution of verb tenses and modals in each move. She found that the past tense was predominant in the results and the methods moves and the present tense was mostly used in the conclusion move. Also, the 'statement of the problem' was realised either by the present $(59.5 \%)$ or the present perfect tense $(30.4 \%)$, and the 'purpose' either by the past (57.1\%) or the present tense (28.6\%). A similar study was carried out by Tseng (2011). As an analytical framework for move analysis, he adopted Swales and Feak's (2004) model which consisted of the moves Background, Aim, Method, Results, and Conclusion. He investigated tense usage in Applied Linguistics RA abstracts and found that the present tense (including the 
present perfect) was used in Move 1 (Background), Move 2 (Aim), and Move 5 (Conclusion) and the past tense was the preferred tense in Move 3 (Method), and Move 4 (Results).

Compared to the finding of studies adopting a 'form-first' approach, Salager-Meyer's (1992) and Tseng's (2011) approach provides more detailed information which might be useful for novice writers. For instance, the information that the purpose move in an abstract is realised by the use of either the past or the present tense is likely to benefit novice writers. The only drawback of these studies is that the terms used to refer to the moves of an abstract are not fully functional but rather refer to the parts of an abstract.

With the exception of the studies reviewed above, there is a lack of research focussing on verb tense usage in academic writing from a functional perspective. Analysis of verb tense usage from a functional perspective in RA introductions, in particular, has not received any attention so far. Hence, the present study is intended to fill in this gap.

The purpose of this study is to investigate verb tense usage in RAls in the field of Applied Linguistics by adopting a 'function-first' approach. The study aims to address the following research questions:

1) What is the distribution of verb tense usage in RAls as a whole?

2) What is the distribution of verb tense usage in the moves of RAls?

3) What is the distribution of verb tense usage in the steps of the moves in RAls?

\section{Methodology}

\subsection{The Corpus}

The corpus consisted of 50 research article introductions (RAIs) published in the 2014 and 2015 issues of five journals - Applied Linguistics (AL), Studies in Second Language Acquisition (SSLA), Language Learning (LL), English for Specific Purposes (ESP) and Journal of Second Language Writing (JSLW). These are among the leading journals in the field of Applied Linguistics with the highest impact factor. The impact factors ranged from 1.453 to 1.773 at the ThompsonReuters journal rankings (Clarivate Analytics). Ten empirical research articles from each journal were randomly selected; special issues were excluded. Theoretical and review articles were also excluded from the corpus because they may not follow the standard IMRD (introductionmethods-results-discussion) pattern. In total, the corpus consisted of 50736 words. The shortest and the longest RAI contained 1580 and 4017 words respectively; the average number of words was 2670. 
İsmet Öztürk | Dil Dergisi-Temmuz 2019 | 30-52

\subsection{Analytical Framework}

\subsubsection{Identifying Functions}

The communicative function of the sentences was determined on the basis Swales' (1990; 2004) CARS (Create a Research Space) model. It contains three moves, each of which is realised by a number of steps. The model used in the analysis of data is presented in Figure 1. It is a mixture of Swales' 1990 and 2004 CARS models. The modification was done by the present researcher.

\section{Move 1 Establishing a territory}

Step 1 Claiming centrality and/or

Step 2 Making topic generalization(s) and/or

Step 3 Reviewing items of previous research

Move 2 Establishing a niche

Step 1 Indicating a gap in the previous research or raising a question about it OR Step 2 Adding to what is known

Move 3 Occupying the niche/Presenting the Present Work

Step 1 (obligatory) Announcing present research descriptively and/or purposively

Step 2 (optional) Presenting research questions or hypotheses

Step 3 (optional) Definitional clarifications

Step 4 (optional) Summarizing methods

Step 5 (PISF*) Announcing principal outcomes

Step 6 (PISF) Stating the value of the present research

Step 7 (PISF) Outlining the structure of the paper

*Probable in some fields

Figure 1. The modified CARS model (based on Swales, 1990, 2004)

The moves and steps in Figure 1. are functional units in the sense that they perform specific communicative functions in discourse. As pointed out by Swales (2004), who introduced these terms, a move is "a discoursal or rhetorical unit that performs a coherent communicative function in a written or spoken discourse" (p. 228). Hence, "at one extreme in can be realized by a clause, at the other by several sentences. It is a functional, not a formal unit" (p. 229). Moves can be considered as 'general' functions and steps as 'specific' functions used in the realisation of each move.

In the coding of moves and steps, the sentence was taken as the basic unit of analysis. Each sentence in the RAls analysed was assigned a move and a step label (e.g., M1S1). In a limited number of cases where a sentence contained multiple clauses, following Holmes (1997) 
and Öztürk (2007), it was assigned to the move and step that appeared more salient. This is exemplified below.

As mentioned by Roberts (1993), the study of multiword units has interested scholars as far back as Saint Augustine ... (SSLA2)

The sentence contains two clauses. The first clause would normally be coded as M1S3 (reviewing items of previous research); however, the focus here is on the second clause as the author emphasises the importance of the topic. The sentence as a whole was coded as M1S1 (claiming centrality) because here 'claiming centrality' seems more salient than 'reviewing items of previous research'.

\subsubsection{Analysis of Verb Tenses}

Following the common practice in the literature (e.g., Salager-Meyer, 1992; Hawes \& Thomas, 1997; Arsyad et al., 2018) the analysis of tenses was based on the finite verb of the main clauses in the sentences. This is exemplified below.

The central issue in the arguments for and against error correction in L2 writing has focused on whether or not writing improves as a consequence of corrective feedback. (JSLW3)

In this sentence the verb tense of the main clause is in the present perfect tense; therefore, the sentence as a whole was coded as Present Perfect.

\subsection{Procedure}

In the coding of data MaxQDA 11 was used. It is a software package developed for qualitative and mixed methods research (https://www.maxqda.com/what-is-maxqda). Each sentence in the RAls was coded for the type of move, step and tense. For example, the sentence given below was coded as M1/S1/Present perfect, where M1 stands for Move 1 (establishing a territory), S1 for Step 1 (claiming centrality) and Present perfect for the verb tense of the sentence.

The rhetorical and organizational structure of the research article (RA) has been a focus of applied linguistics research for the past three decades (AL7).

The procedure enabled the coding of a sentence for the move, step and verb tense type simultaneously, (i.e., both for function and form). Here, the terms 'move' and 'step' are used as functional categories. That is to say; they indicate the function of the sentence. For instance, the function of the sentence above is 'establishing a territory' (general function)/'claiming centrality' (specific function). The tense type (present perfect) is related to the form of the sentence. 
The analysis was carried out mainly by the present researcher. However, a subset of the data (10 introductions) was analysed by an independent researcher specialising in Applied Linguistics. The analysis of both researchers was compared and revised until an agreement was reached.

\section{Results}

\subsection{The Distribution of Verb Tense Usage in RAls as a Whole}

The first research question of the present study addressed the distribution of verb tenses in RAls as a whole. The results are given in Table 1 below:

Table 1. Frequency and Percentage of the Verb Tenses Used in RAI moves

\begin{tabular}{|l|c|c|c|c|c|c|c|c|c|c|c|}
\hline & & \multicolumn{2}{|c|}{$\begin{array}{c}\text { Present } \\
\text { Perfect }\end{array}$} & \multicolumn{2}{c|}{$\begin{array}{c}\text { Simple } \\
\text { Present }\end{array}$} & \multicolumn{2}{c|}{$\begin{array}{c}\text { Simple } \\
\text { Past }\end{array}$} & \multicolumn{3}{|c|}{ Modal } & \multicolumn{2}{c|}{$\begin{array}{c}\text { Present } \\
\text { Cont. }\end{array}$} \\
\cline { 2 - 13 } & $\mathbf{F}$ & $\mathbf{F}$ & $\mathbf{\%}$ & $\mathbf{F}$ & $\mathbf{\%}$ & $\mathbf{F}$ & $\mathbf{\%}$ & $\mathbf{F}$ & $\mathbf{\%}$ & $\mathbf{F}$ & $\%$ \\
\hline $\begin{array}{l}\text { Move 1 Establishing } \\
\text { a territory }\end{array}$ & 3126 & 434 & 13.88 & $\mathbf{1 3 9 7}$ & $\mathbf{4 4 . 6 9}$ & 972 & 31.09 & 320 & 10.24 & 3 & 0.1 \\
\hline $\begin{array}{l}\text { Move 2 Establishing } \\
\text { a niche }\end{array}$ & 252 & 101 & 40.08 & $\mathbf{1 2 1}$ & $\mathbf{4 8 . 0 2}$ & 14 & 5.6 & 16 & 6.35 & 0 & 0 \\
\hline $\begin{array}{l}\text { Move 3 Occupying } \\
\text { the niche / } \\
\text { Presenting the } \\
\text { present work }\end{array}$ & 670 & $\mathbf{7}$ & 1.04 & $\mathbf{4 2 5}$ & $\mathbf{6 3 . 4 3}$ & 154 & 22.98 & 84 & 12.53 & 0 & 0 \\
\hline \multicolumn{1}{|c|}{ TOTAL } & 4048 & 542 & 13.39 & $\mathbf{1 9 4 3}$ & $\mathbf{4 8 . 0 0}$ & 1140 & 28.16 & 420 & 10.38 & 3 & 0.1 \\
\hline
\end{tabular}

The results given in Table 1(the last row) show that in RAls as a whole the simple present is the most frequently used tense (with 1943 occurrences out of 4048, 48\%). It is followed by the simple past tense $(28.16 \%)$, the present perfect tense $(13.39 \%)$ and the modal verbs $(10.38 \%)$. The occurrence of the present continuous is restricted to 3 cases in the whole data $(0.1 \%)$.

This information seems to be of little use to novice writers since it offers a too general picture of verb tense usage in RAls. Therefore, a move analysis of verb tense usage in RAls was carried out.

\subsection{The Distribution of Verb Tense Usage in the Moves of RAls}

The second research question was concerned with the distribution of verb tenses in the moves of RAls. The results are given in the first three rows of Table 1.

To begin with Move 1 (Establishing a territory), the results in Table 1 (the first row) demonstrate that the simple present is the most frequently used tense with 1397 occurrences 
out of 3126 (44.69\%) and is followed by the simple past (31.09\%). These two tenses are followed by the present perfect tense (13.39\%) and the modal verbs (10.39\%).

As for Move 2 (Establishing a niche), the results in Table 1 (the second row) reveal that the simple present tense is the dominant tense (48.08\%) followed closely by the present perfect tense (40.08\%). The use of these two tenses accounts for 88.16 percent of the data. The occurrence of the simple past tense and the modal verbs is restricted to $5.6 \%$ and $6.35 \%$ respectively.

Finally, the results regarding verb tense usage in Move 3 (Occupying the niche / Presenting the Present Work) are shown in Table 1 (the third row) above. The results reveal that in Move 3 the simple present is the most frequently used tense with 425 occurrences out of 670 (63.43\%). It is followed by the simple past tense $(22.98 \%)$ and the modal verbs $(12.53 \%)$. The occurrence of the present perfect tense is restricted to 1.04 per cent.

However, even though the analysis of verb tense usage in the moves of RAls seems more revealing that the analysis of RAls as a whole, for more illuminating findings analysis of the steps in each move was performed. The findings are given below.

\subsection{The Distribution of Verb Tense Usage in Steps of RAI Moves}

The third research question was concerned with the distribution of verb tenses in the steps of each move in RAls. Results regarding verb tense usage in the steps of each move are given below.

\subsubsection{The Distribution of Verb Tenses in Steps of Move 1}

The results regarding verb tense usage in the steps of Move 1(Establishing a territory) are given in Table 2 below.

Table 2. Frequency and Percentage of Verb Tenses in the Steps of Move 1 (Establishing a territory)

\begin{tabular}{|c|c|c|c|c|c|c|c|c|c|c|c|}
\hline \multirow{2}{*}{ Move\&Steps } & \multirow[b]{2}{*}{$\mathbf{F}$} & \multicolumn{2}{|c|}{$\begin{array}{l}\text { Present } \\
\text { Perfect }\end{array}$} & \multicolumn{2}{|c|}{$\begin{array}{l}\text { Simple } \\
\text { Present }\end{array}$} & \multicolumn{2}{|c|}{$\begin{array}{l}\text { Simple } \\
\text { Past }\end{array}$} & \multicolumn{2}{|c|}{ Modal } & \multicolumn{2}{|c|}{$\begin{array}{c}\text { Present } \\
\text { Cont. }\end{array}$} \\
\hline & & $\mathbf{F}$ & $\%$ & $\mathbf{F}$ & $\%$ & $\mathbf{F}$ & $\%$ & $\mathbf{F}$ & $\%$ & $\mathbf{F}$ & $\%$ \\
\hline Step 1 Claiming centrality & 48 & 39 & 81.25 & 8 & 16.70 & 0 & 0 & 0 & 0 & 1 & 2.08 \\
\hline $\begin{array}{l}\text { Step } 2 \text { Making topic } \\
\text { generalization(s) }\end{array}$ & 1724 & 326 & 18.91 & 1100 & 63.81 & 10 & 0.58 & 286 & 16.59 & 2 & 0.12 \\
\hline $\begin{array}{l}\text { Step } 3 \text { Reviewing items of } \\
\text { previous research }\end{array}$ & 1354 & 69 & 5.10 & 289 & 21.34 & 962 & 71.05 & 34 & 2.51 & 0 & 0 \\
\hline
\end{tabular}


The results given in Table 2 (the first row) indicate that Step 1 (Claiming centrality) is predominantly realised by the present perfect tense (in 39 out of 48 occurrences, (81.25\%)).

Claiming centrality has been defined by Swales (1990, p.144) as "appeals to the discourse community whereby members are asked to accept that the research about to be reported is part of a lively, significant or well established research area". An example is given below:

(1) The rhetorical and organizational structure of the research article (RA) has been a focus of applied linguistics research for the past three decades. (AL7)

The present perfect is followed by the simple present tense in 8 out of 48 occurrences (16.7\%). However, there is a significant difference between the occurrences of the two tenses. An example of topic generalisation realised by the simple present tense is given below. :

(2) A considerable amount of research in the field of instructed second language acquisition (SLA) is devoted to exploring pedagogical techniques ... . (LL

Step 2 (Making topic generalisations), on the other hand, is overwhelmingly realised by the simple present tense in 1100 out of 1724 occurrences (63.81\%) (see, Table 2, the second row). It is followed by the present perfect tense (18.91\%) and the modal verbs (16.59\%). An example for each realisation respectively is given below:

(3) These features are theorized to affect the cognitive burden a student experiences during task performance by placing varying demands on learners' cognitive resources. (JSLW9)

(4) Different approaches have been adopted for the investigation of task representation in writing. (JSLW1)

(5) This would require researchers to have a sufficient volume of writing to analyze in order to demonstrate a learner's accuracy level. (JSLW3)

Finally, according to the results in Table 2 (the third row), Step 3 (Reviewing items of previous research) is predominantly realised by the simple past tense (in 962 out of 1354 occurrences, $71.05 \%)$, followed by the simple present tense (21.34\%). The results show that the occurrence of the present perfect is restricted to $5.1 \%$ and the modal verbs to $2.51 \%)$. Extract (6) is an example of Step 3 realised by the use of simple past, and (7) by simple present tense.

(6) Yang and Allison (2004) analysed the macro-structures of two kinds of RAs in applied linguistics, those based on empirical research and those of an argumentative 
İsmet Öztürk | Dil Dergisi-Temmuz 2019 | 30-52

nature (which the authors labeled 'secondary RAs'). (AL7)

(7)

(8) Similarly, Brooks (2009) reports more interaction, negotiation of meaning, and complex language in the paired format as compared to a one-on-one oral interview. (ESP3)

\subsubsection{The Distribution of Verb Tenses in the Steps of Move 2}

The results regarding verb tense usage in the steps of Move 2 (Establishing a niche) are displayed in Table 3. An interesting finding is that Step 2 (Adding to what is known) did not occur at all. The move is realised by Step 1 (Indicating a gap in the previous research or raising a question about it) in all cases. Regarding verb tense usage, the results indicate that the most frequently used tense in Step 1 is the simple present (121 out of 252 occurrences, $48 \%$ ). It was closely followed by present perfect tense with 101 occurrences out of 252 (40\%). According to the Chi-Square test, the $p$-value is .17949; therefore, the result is not significant at $p<.05$. This means that Step 1 is overwhelmingly realised by either the simple present tense or the present perfect tense. In the data, the use of the simple past tense was restricted to $5.56 \%$ and the modal verbs to $6.35 \%$. An example of this usage is provided below:

Table 3. Frequency and Percentage of the Verb Tenses Used in the Steps of Move 2 (Establishing a niche)

\begin{tabular}{|l|c|c|c|c|c|c|c|c|c|}
\hline \multirow{2}{*}{ Move\&Steps } & & \multicolumn{2}{c|}{ Present Perfect } & \multicolumn{2}{c|}{$\begin{array}{c}\text { Simple } \\
\text { Present }\end{array}$} & \multicolumn{2}{c|}{$\begin{array}{c}\text { Simple } \\
\text { Past }\end{array}$} & \multicolumn{2}{c|}{ Modal } \\
\cline { 2 - 10 } & $\mathbf{F}$ & $\mathbf{F}$ & $\mathbf{\%}$ & $\mathbf{F}$ & $\mathbf{\%}$ & $\mathbf{F}$ & $\%$ & F & $\%$ \\
\hline $\begin{array}{l}\text { Step 1 Indicating a gap in the } \\
\text { previous research or raising a } \\
\text { question about it }\end{array}$ & $\mathbf{2 5 2}$ & 101 & 40.08 & $\mathbf{1 2 1}$ & $\mathbf{4 8 . 0 2}$ & 14 & 5.56 & 16 & 6.35 \\
\hline Step 2 Adding to what is known & $\mathbf{0}$ & 0 & 0 & 0 & 0 & 0 & 0 & 0 & 0 \\
\hline
\end{tabular}

Extract (8) below is an example of the simple present tense and (9) is an example of the present perfect tense usage.

(9) Applied linguistics research into mathematical discourse is scarce.(AL7)

(10) To date, no study of written feedback has investigated this.(LL2) 
İsmet Öztürk | Dil Dergisi-Temmuz 2019 | 30-52

\subsubsection{The Distribution of Verb Tenses in the Steps of Move 3}

The results concerning verb tense usage in the steps of Move 3 (Occupying the niche) Presenting the present work) are given in Table 4 below.

Table 4. Frequency and Percentage of the Verb Tenses Used in the Steps of Move 3

\begin{tabular}{|l|c|c|c|c|c|c|c|c|c|}
\hline \multicolumn{2}{|c|}{ Move\&Steps } & \multicolumn{2}{c|}{$\begin{array}{c}\text { Present } \\
\text { Perfect }\end{array}$} & \multicolumn{2}{c|}{$\begin{array}{c}\text { Simple } \\
\text { Present }\end{array}$} & \multicolumn{2}{c|}{$\begin{array}{c}\text { Simple } \\
\text { Past }\end{array}$} & \multicolumn{2}{c|}{ Modal } \\
\hline & F & F & $\%$ & F & $\%$ & F & $\%$ & F & $\%$ \\
\hline $\begin{array}{l}\text { Step 1 (obligatory) Announcing } \\
\text { present research descriptively and/or } \\
\text { purposively }\end{array}$ & 177 & 0 & 0 & $\mathbf{1 2 1}$ & $\mathbf{6 8 . 3 6}$ & 50 & 28.25 & 6 & 3.39 \\
\hline $\begin{array}{l}\text { Step 2 (optional) Presenting research } \\
\text { questions or hypotheses }\end{array}$ & 158 & 1 & 0.63 & $\mathbf{1 0 6}$ & $\mathbf{6 7 . 0 9}$ & 33 & 20.89 & 18 & 11.39 \\
\hline $\begin{array}{l}\text { Step 3 (optional) Definitional } \\
\text { clarifications }\end{array}$ & 22 & 0 & 0 & $\mathbf{1 7}$ & $\mathbf{7 7 . 2 7}$ & 2 & 9.09 & 3 & 13.64 \\
\hline \begin{tabular}{l} 
Step 4 (optional) Summarizing methods \\
\hline
\end{tabular} & 185 & 6 & 3.24 & $\mathbf{9 3}$ & $\mathbf{5 0 . 2 7}$ & 66 & 35.68 & 20 & 10.81 \\
\hline $\begin{array}{l}\text { Step 5 (PISF*) Announcing principal } \\
\text { outcomes }\end{array}$ & 7 & 0 & 0 & $\mathbf{6}$ & $\mathbf{8 5 . 7 1}$ & 0 & 0 & 1 & 14.29 \\
\hline $\begin{array}{l}\text { Step 6 (PISF) Stating the value of the } \\
\text { present research }\end{array}$ & 62 & 0 & 0 & $\mathbf{3 4}$ & $\mathbf{5 4 . 8 4}$ & 1 & 1.61 & 27 & 43.55 \\
\hline $\begin{array}{l}\text { Step 7 (PISF) Outlining the structure of } \\
\text { the paper }\end{array}$ & 59 & 0 & 0 & $\mathbf{4 8}$ & $\mathbf{8 1 . 3 6}$ & 3 & 5.08 & 8 & 13.56 \\
\hline
\end{tabular}

* probable in some fields

To begin with Step 1 (Announcing present research), the results in Table 4 (the first row) indicate that the simple present and the simple past tense are the preferred tenses. The usage of these two tenses accounts for 97 percent of the data. The occurrence of modal verbs was restricted to $3.39 \%$ percent, and no use of the present perfect tense was observed. The simple present tense occurred in 121 out of 670 instances (68.36\%) whereas the simple past tense occurred in 49 out of 670 (28.25\%) cases. This can be taken to mean that most authors announce their research by using the simple present tense, but some use the simple past. Each use is exemplified in (10) and (11) below, respectively:

\section{(11) Simple present}

The current study investigates the validity of the El and the word monitoring tasks as measures of implicit knowledge. (LL10) 
(12) Simple past

The current study investigated the detection and production of novel constructions through two experiments which targeted the learning of the Esperanto transitive construction, addressing three research questions. (LL7)

Step 2 (Presenting research questions or hypotheses) is again realised by the use of the simple present tense (in 106 out of 158 occurrences, 67.09\%) followed by the simple past (33 out of 158, 20.89\%) (see, Table 4, the second row). These are illustrated in (12) and (13) below:

(13) Do learners perceive feedback provided during task-based interaction? (SSLA1)

(14) The following research questions were formulated: (SSLA2)

It should be pointed out, however, that the simple past tense mostly functioned as an introductory sentence whereas the research questions themselves were in the simple present tense as in the following extract.

In light of the issues mentioned above, the following questions were formulated:

(1) What are the effects of cognitive task complexity on syntactic complexity when measured (a) as the ratio of dependent clauses to T-units across all dependent clauses, and (b) as the ratio of dependent clauses to T-units when dependent clauses are measured separately? (JSLW9)

As for Step 3 (Definitional clarifications), the results in Table 4 (the third row) illustrate that it is usually realised by the use of the simple present tense (in 17 out of 22 occurrences, $77.27 \%)$. An example is given in extract (14) below:

(15) We use the term "feedback" to refer to an attempt to draw learners' attention to problems in their writing. (LL2)

In Step 4 (Summarizing methods) the simple present and the simple past are again the two dominant tenses. The simple present is the preferred tense $(50.27 \%)$ and it is followed by the simple past (35.68\%). The occurrence of the modal verbs was restricted to 10.81 percent (see, Table 4, the fourth row). 
The occurrence of Step 5 (Announcing principal outcomes) was restricted; only 7 instances were observed and 6 of them were realised by the simple present tense as in (16) below:

(16) The findings obtained in this study emphasise the growing functional importance of promotional strategies in RA Introductions. (ESP1)

On the other hand, according to the results in Table 4 (the sixth row) in the realisation of Step 6 (Stating the value of the present research) the simple present tense is again the preferred verb tense (in 34 out of 62 occurrences, 54.84\%). However, in contrast to the previous steps where the simple present was followed by the simple past, here it is followed by the modal verbs (in 27 out of 62 occurrences, 43.55\%). These are exemplified in extracts (17) and (18) below:

(17) This is important because academic practices are known to be hard for students to comprehend. (ESP10)

(18) Such a study would be useful, as it could contribute descriptors pertaining to the use of metaphor, which could then be used in training materials.

Finally, regarding Step 7 (Outlining the structure of the paper) the results shown in Table 4 indicate that the simple present is the most preferred tense. 48 out of 59 occurrences $(81.36 \%)$ are realised by the use of this tense as exemplified in the extract (18) below:

(19) In what follows, I first provide an overview of two competing theoretical explanations for age effects on late bilingualism (i.e., the critical period hypothesis $[\mathrm{CPH}]$ vs. the cognitive aging hypothesis [CAH]). Subsequently, I review how recent studies have examined the interlanguage development of L2 oral ability from pronunciation, fluency, vocabulary, and grammar research perspectives. Last, I present the results of the current study ...(SSLA210)

The second place is occupied by the use of the modal verbs (in 8 out of 59 occurrences, 13.56\%). Extract (19) is an example.

(20) In the following text, we will address the theoretical considerations behind researching complexity and accuracy from a dynamic systems perspective, and then we will present the 12-month case study. 


\section{Discussion}

The purpose of the present study was to investigate verb tense usage in RAls by adopting a function-first approach. Functions were determined on the basis of the moves and steps in the CARS model introduced by Swales $(1990,2004)$. This was followed by the analysis of verb tenses used in each step (i.e., function) in order to determine the distribution of verb tenses in the realisation of a particular step.

\subsection{Verb Tense Usage in RAls as a Whole}

The results show that in RAls as a whole the simple present is the most preferred tense $(47.10 \%)$, which is followed by the simple past (28.2\%), present perfect tense (13.4\%) and modal verbs (10.4\%). These findings are in partial agreement with those of Chen (2009), who observed the same order of preference in tense usage in the literature review chapters of PhD dissertations. In his data, the percentage of the simple present tense usage was 70.6, the simple past tense 15.8 , the present perfect 8.9 and other 4.7 . The differences in the percentages may be explained by the fact that his data contained introductions from the fields in both the humanities and sciences whereas in the present study the focus was on RAls in the field of Applied Linguistics.

However, as pointed out earlier, knowing which tenses are used and what their distribution is in RAls as a whole is unlikely to benefit novice research writers since different parts of an introduction may require different tenses. Therefore, in this study, the analysis of the introductions as a whole was followed by the analysis of tense usage in the constituent moves of the introductions.

\subsection{Verb Tense Usage in the Moves of RAls}

As indicated earlier, in the CARS model proposed by Swales $(1990,2004)$ an introduction consists of three moves: Establishing a territory, Establishing a niche, and Occupying the niche (or Presenting the present work). The findings of this study indicate that in Establishing a territory (Move 1) the simple present tense is the preferred tense (44.69\%), and is followed by the simple past $(31.09 \%)$. The difference is statistically significant $(p<.00001)$. As for Establishing a niche (Move 2), the simple present tense is again dominant (48.02\%), but this time it is followed closely by the present perfect $(40.08 \%)$. Here, the difference is not statistically significant (the $p$-value is 17949). This can be taken to mean that it is up to the writer to choose between the two tenses. Here, an interesting finding is that in this Move the use of the simple past tense falls to 5.6 percent (from 31.09\% in Move 1). Finally, in Occupying the niche/Presenting the present work (Move 3 ) again the simple present is by far the predominant tense $(63.43 \%$ ) and is followed by the simple past $(22.98 \%)(p<.00001)$. In this move, there is a sharp fall in the use of the present perfect tense from $13.88 \%$ in Move 1 and $40.08 \%$ in Move 2 to $1.04 \%$ in Move 3, which is an interesting finding. 
If we are to compare these findings with the findings regarding tense usage in RAls as a whole as discussed in 4.1 above, it can be suggested that the move analysis provides more specific results than the analysis of verb tense usage in RAls as a whole. For instance, the use of the present perfect tense in RAls as a whole is $13.39 \%$, but its use rises to $40.08 \%$ in Move 2 and falls to $1.04 \%$ in Move 3 (see, Table 1). Similarly, while the use of the simple past tense is $28.16 \%$ in RAls as a whole, its use rises to $31.09 \%$ in Move 1and falls to $6.35 \%$ in Move 2; the use of the simple present tense is $48 \%$ in RAls as a whole, but its use rises to $63.43 \%$ in Move 3 . However, as indicated earlier a Move consists of several steps; therefore, an analysis of verb tense usage in the steps of each move may provide valuable insights into the issue of tense usage in RAls. This issue is discussed in the following sections.

\subsection{Verb Tense Usage in the Steps of the Moves in RAls}

As indicated earlier Move 1 (Establishing a territory) may be realised by three steps Claiming Centrality (Step1), Making topic generalisations (Step 2) and Reviewing items of previous research (Step 3). The findings show that the analysis of the step enables us to associate a particular tense with a particular step more clearly than the move analysis.

As far as the Move 1 steps are concerned, the findings demonstrate that in Step1 (Claiming Centrality) the present perfect tense is the most preferred tense (81.25\%). In Step 2 (Making topic generalisations) the simple present tense is predominant (63.81\%), but the use of the present perfect is not very low (18.91\%). Therefore, further research seems necessary here to see whether there are functional differences between the two tenses. Finally, in Step 3 (Reviewing items of previous research) the simple past tense is by far the most dominant tense (71.05\%).

As for the steps in Move 2 (Establishing a niche), the findings show that Step 2 (Adding to what is known) did not occur in the data at all, which means that it is not a step preferred by the researchers in the field of Applied Linguistics. Instead, Step 1 (Indicating a gap in the previous research or raising a question about it) is the preferred step. The findings indicate that it is realised by either the simple present $(48.02 \%)$ or the present perfect $(40.08 \%)$. Contextual analysis suggests that there are not any functional differences between the two tenses; it is up to the author to decide which tense to choose. However, further research is needed to verify this observation.

To proceed to the discussion of the results concerning tense usage in the steps in Move 3 (Occupying the niche/Presenting the present work), the findings show that the simple present tense is the preferred step with a different distribution across the steps. The use of the present perfect tense is very low ranging from $0.63 \%$ to $3.24 \%$, which is an interesting finding. 
In Step1 (Announcing present research...) the simple present is the preferred tense (68.36), but the use of the simple past tense is not low (28.25). This suggests that in announcing their research while most authors prefer the simple present tense, some choose the simple past tense. This finding confirms Swales and Feak's (2004, p.191) suggestion that "there is an increasing tendency to choose the present". In Step 2 (Presenting research questions or hypotheses) the simple present is again the predominant tense $(67.09 \%)$ and is followed by the simple past tense (20.89\%). However, the contextual analysis suggests that the introductory sentence (e.g., The following research questions were formulated) is usually in the simple past tense, but the research questions are realised by the use of the simple present tense. Considerably higher usage of the simple past tense (35.68\%) is also observable in Step 4 (Summarising methods), but again the simple present tense is the dominant tense (50.27\%). However, here the percentage of the simple past is higher than the other steps of Move 3. This may have resulted from the authors' conception that the methods should be expressed in the past. In Step 6 (Stating the value of the present research) the simple present is again the most preferred tense $(54.84 \%)$, but here it is followed by the use of modal verbs (43.55\%). Higher use of the modal verbs in this step can be explained by the fact that here authors evaluate their own work in terms of its contribution to their field of inquiry, and therefore, they tend to avoid commitment or making bold statements. Further research may shed light on the issue.

In the remaining steps, the simple present tense is the preferred tense. In Step 3 (Definitional clarification) and Step 5 (Announcing principal outcomes) authors generally use the simple present tense $(77.27 \%$ and $85.71 \%$, respectively), but the occurrence of these steps in the corpus used in the present study is limited. The frequency of occurrence of the former was 22 and the latter 7. Finally, in Step 7 (Outlining the structure of the paper), the simple present tense is by far the most predominant tense (81.36\%).

The findings discussed above reveal that in the study of verb tense usage the analysis of steps, which is based on specific contextual functions, provides more accurate results that the analysis of introductions as a whole or the Move analysis. For instance, Hawes and Thomas (1997) suggest that in RA introductions the past tense is the most frequently used tense and is followed by the present perfect and the present tense in research articles, but they do not mention which functions these tenses realise. The same goes for the Move analysis because a move consists of several steps which may be realised by the use of different tenses.

In view of the findings of the present study, it may be argued that previous research has failed to provide such a detailed account of tense usage in RAls because of a focus on form first. A function-first approach takes functions as a point of departure, and consequently, enables us to identify not only the preferred verb tenses in the construction of RAls but also the other less used tenses. However, the issue of whether the use of other tenses points to a more specific functional difference requires further research. 


\section{Conclusion}

The present study explored verb tense usage in RAls in the field of Applied Linguistics by adopting a function-first approach. Functions were identified on the basis of Swales' (1990, 2004) moves and steps model (i.e., CARS model). The study revealed that in the investigation of verb tense usage in RAls an analysis based on specific functions (i.e., steps) provides more illuminating and fruitful results. The findings indicate that there is a link between function and verb tense usage in the construction of RAls. However, the findings are based on a single field of inquiry (Applied Linguistics), and therefore, they are generalizable to this field only. Also, the corpus consisted of 50 research articles.

Further research with a larger corpus and with a focus on different disciplines or fields can be profitably conducted. Also, the study of verb tense usage in the other sections of RAs in terms of the approach used in this study may provide significant insights. Given the suggestions (e.g., Swales, 1990) that writing RAs, and particularly RA introductions, is difficult and troublesome, the findings have implications for both teaching and learning academic writing. Novice researchers and non-native speaker of English should be made aware of the functions found in RAls and the tenses used in the realisation of each function. In this way their RAls would confirm with the conventions and expectation of the academic community and their chances of being published increased.

\section{References}

Arsyad, S., Zaim, M., \& Susyla, D. (2019). Review and citation style in research article introductions: A comparative study between national and international English-medium journals in medıcal sciences. Discourse and Interaction, 11(1), 28-51.

Chen, M. (2009). Tense of reporting in dissertation literature reviews. Journal of Cambridge Studies, 4(2), 139-150.

Cortes, V. (2013). The purpose of this study is to: Connecting lexical bundles and moves in research article introductions. Journal of English for Academic Purposes, 12(1), 33-43. doi:https://doi.org/10.1016/j.jeap.2012.11.002

Del Saz Rubio, M. M. (2011). A pragmatic approach to the macro-structure and metadiscoursal features of research article introductions in the field of Agricultural Sciences. English for Specific Purposes, 30(4), 258-271.

Durrant, P., \& Mathews-Aydınlı, J. (2011). A function-first approach to identifying formulaic language in academic writing. English for Specific Purposes, 30(1), 58-72.

Gunawardena, C. N. (1989). The present perfect in the rhetorical divisions of biology and biochemistry journal articles. English for Specific Purposes, 8(3), 265-273. 
İsmet Öztürk | Dil Dergisi-Temmuz 2019 | 30-52

Hawes, T., \& Thomas, S. (1997). Tense choices in citations. Research in the Teaching of English, 31(3), 393-414.

Hirano, E. (2009). Research article introductions in English for specific purposes: A comparison between Brazilian Portuguese and English. English for Specific Purposes, 28(4), 240-250. doi:https://doi.org/10.1016/j.esp.2009.02.001

Holmes, R. (1997). Genre analysis, and the social sciences: An investigation of the structure of research article discussion sections in three disciplines. English for Specific Purposes, 16(4), 321-337.

Hyland, K., \& Jiang, F. (2017). Points of reference: Changing patterns of academic citation. Applied Linguistics, 4O(1), 64-85. https://doi.org/10.1093/applin/amx012

Öztürk, I. (2007). The textual organisation of research article introductions in applied linguistics: Variability within a single discipline. English for Specific Purposes, 26(1), 25-38. doi:https:// doi.org/10.1016/j.esp.2005.12.003

Salager-Meyer, F. (1992). A text-type and move analysis study of verb tense and modality distribution in medical English abstracts. English for Specific Purposes, 11(2), 93-113.

Samaie, M., Khosravian, F., \& Boghayeri, M. (2014). The frequency and types of hedges in research article Introductions by Persian and English native authors. Procedia-Social and Behavioral Sciences, 98, 1678-1685.

Samraj, B. (2002). Introductions in research articles: variations across disciplines. English for Specific Purposes, 21(1), 1-17. doi:https://doi.org/10.1016/S0889-4906(00)00023-5

Swales, J. M. (1990). Genre analysis: English in Academic and Research Settings. Cambridge: CUP.

Swales, J. M. (2004). Research Genres: Explorations and Applications. Cambridge: Cambridge University Press.

Swales, J. M., \& Feak, C. B. (2004). Academic Writing for Graduate Students. (2nd ed.). Ann Arbor: University of Michigan Press.

Tseng, F. P. (2011). Analyses of move structure and verb tense of research article abstracts in applied linguistics. International Journal of English Linguistics, 1(2), 27-39.

\section{Appendix - Articles in the corpus}

AL1. Fordyce, K. (2013). The differential effects of explicit and implicit instruction on EFL learners' use of epistemic stance. Applied Linguistics, 35, 6-28.

AL2. Ko, S. (2013). The nature of multiple responses to teachers' questions. Applied Linguistics, 35 , 48-62. 
AL3. Polat, B., \& Kim, Y. (2014). Dynamics of complexity and accuracy: A longitudinal case study of advanced untutored development. Applied Linguistics, 35, 184-207.

AL4. Littlemore, J., Krennmayr, T., Turner, J., \& Turner, S. (2013). An investigation into metaphor use at different levels of second language writing. Applied Linguistics, 35(2), 117-144.

AL5. Zhang, X., \& Lu, X. (2013). A longitudinal study of receptive vocabulary breadth knowledge growth and vocabulary fluency development. Applied Linguistics, 35, 283-304.

AL6. Jakonen, T., \& Morton, T. (2013). Epistemic search sequences in peer interaction in a contentbased language classroom. Applied Linguistics, 36(1), 73-94.

AL7. Kuteeva, M., \& McGrath, L. (2013). The theoretical research article as a reflection of disciplinary practices: The case of pure mathematics. Applied Linguistics, 36, 215-235.

AL8. Wang, C., \& Wang, M. (2014). Effect of alignment on L2 written production. Applied Linguistics, 36, 503-526.

AL9. Crossley, S. A., Salsbury, T., \& Mcnamara, D. S. (2014). Assessing lexical proficiency using analytic ratings: A case for collocation accuracy. Applied Linguistics, 36(5), 570-590.

AL10. Plonsky, L., Egbert, J., \& Laflair, G. T. (2014). Bootstrapping in applied linguistics: Assessing its potential using shared data. Applied Linguistics, 36, 591-610.

ESP1. Martín, P., \& Pérez, I. K. L. (2014). Convincing peers of the value of one's research: A genre analysis of rhetorical promotion in academic texts. English for Specific Purposes, 34, 1-13.

ESP2. Dressen-Hammouda, D. (2014). Measuring the voice of disciplinarity in scientific writing: A longitudinal exploration of experienced writers in geology. English for Specific Purposes, 34, 14-25.

ESP3. Ockey, G. J. (2014). The potential of the L2 group oral to elicit discourse with a mutual contingency pattern and afford equal speaking rights in an ESP context. English for Specific Purposes, 35, 17-29.

ESP4. Gea-Valor, M. L., Rey-Rocha, J., \& Moreno, A. I. (2014). Publishing research in the international context: An analysis of Spanish scholars' academic writing needs in the social sciences. English for Specific Purposes, 36, 47-59.

ESP5. Yang, W. (2015). "Call for papers": Analysis of the schematic structure and lexico-grammar of CFPs for academic conferences. English for Specific Purposes, 37, 39-51.

ESP6. Rowley-Jolivet, E. (2015). Quantification in conference talks and proceedings articles in engineering. English for Specific Purposes, 38, 11-22.

ESP7. Wilcox, K. C., \& Jeffery, J. V. (2015). Adolescent English language learners' stances toward disciplinary writing. English for Specific Purposes, 38, 44-56.

ESP8. Mežek, Š., Pecorari, D., Shaw, P., Irvine, A., \& Malmström, H. (2015). Learning subjectspecific $\mathrm{L} 2$ terminology: The effect of medium and order of exposure. English for Specific Purposes, 38, 57-69. 
ESP9. Gablasova, D. (2015). Learning technical words through L1 and L2: Completeness and accuracy of word meanings. English for Specific Purposes, 39, 62-74.

ESP10. Soler-Monreal, C. (2015). Announcing one's work in PhD theses in computer science: A comparison of Move 3 in literature reviews written in English L1, English L2 and Spanish L1. English for Specific Purposes, 40, 27-41.

JSLW1. Nicolás-Conesa, F., de Larios, J. R., \& Coyle, Y. (2014). Development of EFL students' mental models of writing and their effects on performance. Journal of Second Language Writing, 24, 1-19.

JSLW2. McDonough, K., Crawford, W. J., \& De Vleeschauwer, J. (2014). Summary writing in a Thai EFL university context. Journal of second language writing, 24, 20-32.

JSLW3. Evans, N. W., Hartshorn, K. J., Cox, T. L., \& De Jel, T. M. (2014). Measuring written linguistic accuracy with weighted clause ratios: A question of validity. Journal of Second Language Writing, 24, 33-50.

JSLW4. Yang, C., Hu, G., \& Zhang, L. J. (2014). Reactivity of concurrent verbal reporting in second language writing. Journal of Second Language Writing, 24, 51-70.

JSLW5. Fujioka, M. (2014). L2 student-US professor interactions through disciplinary writing assignments: An activity theory perspective. Journal of Second Language Writing, 25, 40-58.

JSLW6. Junqueira, L., \& Payant, C. (2015). "I just want to do it right, but it's so hard": A novice teacher's written feedback beliefs and practices. Journal of Second Language Writing, 27, 19-36.

JSLW7. Knoch, U., Rouhshad, A., Oon, S. P., \& Storch, N. (2015). What happens to ESL students' writing after three years of study at an English medium university?. Journal of Second Language Writing, 28, 39-52.

JSLW8. Worden, D. (2015). Developing writing concepts for teaching purposes: Preservice L2 writing teachers' developing conceptual understanding of parallelism. Journal of Second Language Writing, 30, 19-30.

JSLW9. Frear, M. W., \& Bitchener, J. (2015). The effects of cognitive task complexity on writing complexity. Journal of Second Language Writing, 30, 45-57.

JSLW10. Liu, Q., \& Brown, D. (2015). Methodological synthesis of research on the effectiveness of corrective feedback in L2 writing. Journal of Second Language Writing, 30, 66-81.

LL1. Bell, N., Skalicky, S., \& Salsbury, T. (2014). Multicompetence in L2 language play: A longitudinal case study. Language Learning, 64(1), 72-102.

LL2. Shintani, N., Ellis, R., \& Suzuki, W. (2014). Effects of written feedback and revision on learners' accuracy in using two English grammatical structures. Language Learning, 64(1), 103131. 
LL3. Chrabaszcz, A., \& Gor, K. (2014). Context effects in the processing of phonolexical ambiguity in L2. Language Learning, 64, 415-455.

LL4. Bosker, H. R., Quené, H., Sanders, T., \& Jong, N. H. (2014). The perception of fluency in native and nonnative speech. Language Learning, 64, 579-614.

LL5. Révész, A., Sachs, R., \& Hama, M. (2014). The effects of task complexity and input frequency on the acquisition of the past counterfactual construction through recasts. Language Learning, 64, 615-650.

LL6. Roehr-Brackin, K. (2014). Explicit knowledge and processes from a usage-based perspective: The developmental trajectory of an instructed L2 learner. Language Learning, 64(4), 771-808.

LL7. McDonough, K., \& Fulga, A. (2015). The detection and primed production of novel constructions. Language Learning, 65, 326-357.

LL8. Saito, K. (2015). Experience effects on the development of late second language learners' oral proficiency. Language Learning, 65, 563-595.

LL9. Thomas, M. (2015). Air writing as a technique for the acquisition of Sino-Japanese characters by second language learners. Language Learning, 65(3), 631-659.

LL10. Suzuki, Y., \& DeKeyser, R. (2015). Comparing elicited imitation and word monitoring as measures of implicit knowledge. Language Learning, 65(4), 860-895.

SSLA1. Gurzynski-Weiss, L., \& Baralt, M. (2014). Exploring learner perception and use of taskbased interactional feedback in FTF and CMC modes. Studies in Second Language Acquisition, 36, 1-37.

SSLA2. Edmonds, A. (2014). Conventional expressions: Investigating pragmatics and processing. Studies in Second Language Acquisition, 36(1), 69-99.

SSLA3. Coyle, Y., \& de Larios, J. R. (2014). Exploring the role played by error correction and models on children's reported noticing and output production in a L2 writing task. Studies in Second Language Acquisition, 36(3), 451-485.

SSLA4. Kanwit, M., \& Geeslin, K. L. (2014). The Interpretation of Spanish Subjunctive and Indicative Forms in Adverbial Clauses. Studies in Second Language Acquisition, 36, 487-533.

SSLA5. Grey, S., Williams, J. N., \& Rebuschat, P. (2014). Incidental exposure and L3 learning of morphosyntax. Studies in Second Language Acquisition, 36, 611-645.

SSLA6. Miller, A. K. (2015). Intermediate traces and intermediate learners: Evidence for the use of intermediate structure during sentence processing in second language French. Studies in Second Language Acquisition, 37, 487-516.

SSLA7. Kim, Y., Payant, C., \& Pearson, P. (2015). The intersection of task-based interaction, task complexity, and working memory: L2 question development through recasts in a laboratory setting. Studies in Second Language Acquisition, 37(3), 549-581. 
İsmet Öztürk | Dil Dergisi-Temmuz 2019 | 30-52

SSLA8. Huang, B. H., \& Jun, S. A. (2015). Age matters, and so may raters: Rater differences in the assessment of foreign accents. Studies in Second Language Acquisition, 37(4), 623-650.

SSLA9. Nakata, T. (2015). Effects of expanding and equal spacing on second language vocabulary learning: Does gradually increasing spacing increase vocabulary learning?. Studies in Second Language Acquisition, 37(4), 677-711.

SSLA10. Saito, K. (2015). The role of age of acquisition in late second language oral proficiency attainment. Studies in Second Language Acquisition, 37, 713-743. 